\title{
Pelatihan Pengelolaan Sampah Rumah Tangga dengan Metode Komposting di Desa Kerinjing, Kabupaten Ogan Ilir
}

\author{
Imelda ${ }^{1}$, Saadah Yuliana ${ }^{1}$, Deassy Apriani ${ }^{1}$, Sri Andaiyani ${ }^{1 *}$ \\ ${ }^{1}$ Jurusan Ekonomi Pembangunan, Fakultas Ekonomi, Universitas Sriwijaya, Indonesia \\ *Email korespondensi: sriandaiyani@fe.unsri.ac.id; +6285273233051
}

Info Artikel: Diterima: 21 Agustus, 2020; Diterima: 27 September, 2020; Dipublikasi: 16 Oktober, 2020

\begin{abstract}
Abstrak: Kegiatan pengabdian kepada masyarakat ini dilakukan di Desa Kerinjing, Kecamatan Tanjung Raja, Ogan Ilir yang merupakan salah satu desa binaan dari Fakultas Ekonomi Universitas Sriwijaya. Pelatihan pengelolaan kegiatan ini diharapkan dapat membantu masyarakat, khususnya ibu rumah tangga untuk memanfaatkan sampah rumah tangga menjadi sesuatu yang bermanfaat seperti membuat kompos dengan menggunakan metode komposting. Metode komposting merupakan teknik menghasilkan kompos yang digunakan sebagai pupuk maupun penguat struktur tanah. Komposting digunakan untuk mempercepat proses degradasi bahan organik dengan bantuan mikroba. Dengan adanya pembinaan tentang sampah rumah tangga menjadi pupuk kompos, maka akan mengurangi volume sampah rumah tangga yang sekarang ini semakin meningkat seiring bertambahnya jumlah penduduk.
\end{abstract}

Kata Kunci: Sampah rumah tangga, Metode composting, Pupuk

Kutipan:

Imelda, I., Yuliana, S., Apriani, D., \& Andaiyani, S. (2020). Pelatihan Pengelolaan Sampah Rumah Tangga Dengan Metode Kompostingdi Desa Kerinjing, Kabupaten Ogan Ilir. Sricommerce: Journal of Sriwijaya Community Services, 1(2): 107-114. DOI: https://doi.org/10.29259/jscs.v1i2.19

\section{PENDAHULUAN}

Kesehatan lingkungan pada hakekatnya adalah suatu kondisi atau keadaan lingkungan yang optimum sehingga berpengaruh positif terhadap terwujudnya status kesehatan yang optimum pula. Ruang lingkup kesehatan lingkungan tersebut antara lain: perumahan, pembuangan kotoran manusia, penyediaan air bersih, pembuangan sampah, pembuangan air kotor, rumah hewan ternak (kandang), dan sebagainya (Notoatmojo, 2005).

Sanitasi lingkungan merupakan usaha-usaha pengawasan terhadap semua faktor yang ada dalam lingkungan fisik yang memberi pengaruh baik atau memberi pengaruh buruk terhadap kesehatan, fisik, mental, dan kesejahteraan sosial (Puspitawati \& Sulistyarini, 2013). Pengaruh lingkungan rumah terhadap kegiatan sehari-hari tidaklah secara langsung.Lingkungan yang kelihatannya tidak memiliki potensi bahaya ternyata dapat menimbulkan gangguan kesehatan penghuninya.

Sampah rumah tangga merupakan salah satu sumber sampah yang cukup besar peranannya dalam pencemaran lingkungan (Angeliana, 2016). Keberadaan sampah dapat menimbulkan pencemaran tanah dan air, menimbulkan bau tidak sedap, menjadi sarang binatang yang merupakan sumber penyakit, serta mengganggu keindahan.Namun demikian, keberadaan sampah dapat dikurangi dan dikendalikan (diminimalkan).

Keberadaan sampah rumah tangga di suatu lingkungan tidak bisa dihindarkan. Hal ini disebabkan pengelolaan sampah yang masih didominasi sistem pengumpulan sampah, pengangkutan sampah, dan pembuangan ke Tempat Pemrosesan Akhir (TPA) atau bertumpu pada 
pendekatan akhir atau end-of-pipe (Suparmini dkk, 2013).Pengelolaan sampah masih kurang mendapat penanganan yang optimal dari berbagai pihak, baik dari masyarakat setempat ataupun pemerintah daerah.

Peran masyarakat dalam pengelolaan sampah diperlukan tidak hanya sebatas membuang sampah di tempat yang seharusnya, namun diharapkan termasuk juga pengolahan sampah yang memberikan manfaat kembali bagi masyarakat itu sendiri. Beberapa permasalahan yang teridentifikasi di lokasi pengabdian yaitu Desa Kerinjing, Kecamatan Tanjung Raja, Kabupaten Ogan Ilir adalah sebagai berikut:

1. Adanya peningkatan volume sampah seiring dengan meningkatnya jumlah penduduk;

2. Pola konsumsi masyarakat yang mempengaruhi peningkatan volume sampah;

3. Adanya variasi jenis sampah;

4. Peran masyarakat dalam pengelolaan sampah kebanyakan masih sebatas membuang sampah di tempat yang seharusnya, belum pada pengelolaan sampah yang memberikan manfaat kembali kepada masyarakat; serta

5. Masyarakat belum diberdayakan dalam pengelolaan sampah rumah tangga dengan metode komposting.

Dalam hal ini sebagai salah satu bentuk tanggung jawab dosen dalam melaksanakan Tridarma perguruan Tinggi, maka perlu diadakan pengabdian pada masyarakat berupa pelatihan pengelolaan sampah rumah tanga dengan metode sederhana, yaitu komposting. Dengan adanya pelatihan ini diharapkan sampah rumah tangga, khususnya sampah organik selanjutnya dapat dijadikan pupuk kompos yang dapat menyuburkan tanaman, bahkan dapat dijual kepada konsumen yang membutuhkan, sekaligus dapat menambah penghasilan.

Wanita memiliki peran penting dalam pengelolaan sampah rumah tangga, terkait salah satu perannya sebagai ibu rumah tangga.Desa Kerinjing merupakan salah satu desa di Kecamatan Tanjung Raja Kabupaten Ogan Ilir yang memiliki kegiatan rutin pertemuan ibu-ibu PKK.Diharapkan dengan adanya pelatihan bagi ibu-ibu PKK perwakilan dusun-dusun di Desa Kerinjing tentang pengelolaan sampah rumah tangga dengan metode komposting yang dikemas dalam paket pengabdian masyarakat oleh Tim Dosen dari Fakultas Ekonomi Universitas Sriwijaya. Dengan demikian, dapat ditularkan kepada ibu-ibu di lingkungan sekitarnya sehingga akan sangat membantu dalam menjaga kebersihan lingkungan, mengurangi volume sampah yang dibuang ke lingkungan, menyuburkan tanaman di pekarangan/ lahan pertanian, dan peningkatan pendapatan.

Berdasarkan pertimbangan urgensi permasalahan yang teridentifikasi di atas, maka rumusan masalah yang hendak dicari solusinya melalui kegiatan pelatihan ini adalah: (1) Bagaimana meningkatkan pengetahuan masyarakat tentang pengelolaan sampah rumah tangga dengan metode komposting? dan (2) Bagaimana memberdayakan masyarakat dalam pengelolaan sampah rumah tangga dengan metode komposting?

Tujuan dilakukannya kegiatan pengabdian masyarakat adalah untuk meningkatkan pengetahuan dan memberdayakan masyarakat tentang pengeloaan sampah. Manfaat yang diharapakn dari kegiatan pengabdian kepada masyarakat adalah pertama, sebagai wahana untuk meningkatkan pengetahuan dan wawasan khalayak sasaran dalam pengelolaan sampah rumah tangga dengan metode komposting. Kedua, untuk memberikan alternatif pengeloaan sampah rumah tangga di desa Kerinjing, yang secara tidak langsung juga memberdayakan masyarakat untuk mengolah sampah organik menjadi pupuk kompos yang selanjutnya dapat untuk pupuk tanaman ataupun dijual.

\section{STUDI PUSTAKA}

\subsection{Pengelolaan Sampah Rumah Tangga}

Manusia melakukan aktivitas untuk kelangsungan hidupnya. makan, minum, mencuci, bekerja merupakan beberapa contoh aktivitas. Setiap aktivitas manusia akan menghasilkan sisa-sisa tertentu. Sampah adalah sisa-sisa aktivitas manusia dan alam yang belum memiliki nilai ekonomis, 
sehingga perlu dikelola supaya tidak mencemari lingkungan. Sampah jika dibiarkan saja akan mengganggu kebersihan lingkungan secara umum. Sampah dapat dibedakan menjadi dua macam, yaitu:

\section{Sampah Padat (Anorganik)}

Sampah anorganik adalah sampah yang terdiri atas bahan-bahan anorganik. Sebagai contoh bahan-bahan anorganik adalah bahan logam, plastik, kaca, karet, dan kaleng. Sifat sampah anorganik adalah tahan lama dan sukar membusuk.Sampah ini tidak mudah diuraikan oleh mikroorganisme tanah.Apabila dibuang sembarangan, sampah anorganik dapat menimbulkan pencemaran tanah.

\section{Sampah Basah (Organik)}

Sampah organik adalah sampah yang terdiri atas bahan-bahan organik. Sifat sampah organik adalah tidak tahan lama dan cepat membusuk.Biasanya sampah jenis ini berasal dari makhluk hidup.Contohnya adalah sayur-sayuran, buah-buah yang membusuk, sisa nasi, daun, dan sebagainya.Sampah organik mudah diuraikan mikroorganisme tanah. Hanya saja jenis sampah akan menimbulkan bau kurang sedap jika tidak dikelola dengan baik, sedangkan sampah yang dikelola berdasarkan Undang-Undang No 18 tahun 2008, terdiri dari: sampah rumah tangga; sampah sejenis sampah rumah tangga; serta sampah spesifik. Sampah rumah tanga yaitu sampah yang berasal dari kegiatan sehari-hari dalam rumah tangga, tidak termasuk tinja dan sampah spesifik. Jenis sampah rumah tangga yaitu sampah yang berasal dari kawasan komersial, kawasan industri, kasawan khusus, fasilitas sosial, fasilitas umum, dan/ atau fasilitas lainnya. Sampah spesifik yaitu meliputi:

a. sampah yang mengandung bahan berbahaya dan beracun;

b. sampah yang mengandung limbah bahan berbahaya dan beracun;

c. sampah yang timbul akibat bencana;

d. puing bongkaran bangunan;

e. sampah yang secara teknologi belum dapat diolah;

f. sampah yang timbul secara tidak periodik.

Beberapa teknik yang digunakan untuk pengelolaan sampah antara lain sampah diolah menjadi kompos yaitu menimbun sampah di tanah untuk jangka waktu tertentu hingga membusuk; sampah digunakan sebagai makanan ternak, umumnya sampah dari sayur dan buah di pasar tradisional; metode landfill yaitu membuang dan menumpuk sampah di tanah yang rendah pada area terbuka; metode sanitary landfill yaitu menutup sampah dengan diuruk tanah; metode pulverisation yaitu metode membuang sampah langsung ke laut lepas setelah dihancurkan menjadi potongan-potongan kecil; serta metode incineration yaitu pembakaran sampah baik dengan cara sederhana maupun modern.

\subsection{Metode Komposting}

Teknologi yang umum digunakan dalam proses lanjutan setelah sampah ditimbun di TPA yaitu komposting. Metode komposting merupakan teknik menghasilkan kompos yang digunakan sebagai pupuk maupun penguat struktur tanah. Komposting digunakan untuk mempercepat proses degradasi bahan organik dengan bantuan mikroba. Secara alami, komposting berlangsung cukup lama, biasanya 3 sampai 4 bulan.

Sampah organik secara alami akan mengalami peruraian oleh berbagai jenis mikroba, binatang yang hidup di tanah, enzim dan jamur. Proses peruraian ini memerlukan kondisi tertentu, yaitu suhu, udara dan kelembaban. Makin cocok kondisinya, makin cepat pembentukan kompos, dalam 4-6 minggu sudah jadi. Apabila sampah organik ditimbun saja, baru berbulan-bulan kemudian menjadi kompos. Dalam proses pengomposan akan timbul panas karena aktivitas mikroba. Ini pertanda mikroba mengunyah bahan organik dan merubahnya menjadi kompos. Suhu optimal untk pengomposan dan harus dipertahankan adalah $45^{\circ} \mathrm{C}-65^{\circ} \mathrm{C}$.Jika terlalu panas harus dibolak-balik, setidak-tidaknya setiap 7 hari. 
Untuk mempercepat komposting, diperlukan adanya perlakuan khusus, seperti penggunaan bioreaktor khusus, campuran bahan organik, dan sumber mikroba pengurai. Sumber mikroba pengurai bisa kita buat sendiri dengan cara mencampurkan 1 liter air, tempe, serutan gula merah dan fermipan (pengembang roti) kedalam satu wadah. Selain menggunakan tempe, pembuatan mikroba pengurai bias juga menggunakan nasi dan terasi yang dicampurkan. Setelah dicampurkan jadi satu, tutup rapat dan diamkan selama 4 sampai 5 hari. Setelah 4 sampai 5 hari, air tersebut bisa kita jadikan sumber mikroba pengurai agar kumpulan sampah rumah tangga yang dikumpulkan tersebut lebih cepat proses penguraianya.

Komposting dapat dilakukan dalam skala besar maupun rumah tangga. Komposting skala rumah tangga menggunakan drum khusus yang didesain untuk menampung sampah rumah tangga dengan metode komposting. Adapun keuntungan komposting skala rumah tangga yaitu: tidak membutuhkan lahan yang luas; tidak menghasilkan bau yang mengganggu; mudah dilakukan dan kualitas kompos lebih baik. Dalam komposting perlu adanya upaya menghindari memasukkan cangkang telur, daging, dan tulang karena akan memperlambat proses pengomposan dan menimbulkan bau busuk. Beberapa jenis komposter yaitu komposter tertanam; komposter dengan aerator; komposter takakura; dan komposter tanpa aerator.

Pada dasarnya kompos dapat meningkatkan kesuburan kimia dan fiisik tanah yang selanjutnya akan meningkatkan produksi tanaman. Pada tanaman hortikultura (buah-buahan, tanaman hias, dan sayuran) atau tanaman yang sifatnya perishable ini hampir tidak mungkin ditanam tanpa kompos. Demikian juga di bidang perkebunan, penggunaan kompos terbukti dapat meningkatkan produksi tanaman. Di bidang kehutanan, tanaman akan tumbuh lebih baik dengan kompos. Sementara itu, pada perikanan, umur pemeliharaan ikan berkurang dan pada tambak, umur pemeliharaan 7 bulan menjadi 5-6 bulan.

\subsection{Pengelolaan Sampah Dengan Membuatnya Menjadi Kompos}

Salah satu dari pola hidup hijau yang dapat kita laksanakan adalah mengelola sampah organik rumah tangga, dengan membuatnya menjadi kompos.Kompos adalah pupuk yang dibuat dari sampah organik.Pembuatannya tidak terlalu rumit, tidak memerlukan tempat luas dan tidak memerlukan banyak peralatan dan biaya. Hanya memerlukan persiapan pendahuluan, sesudah itu kalau sudah rutin, tidak merepotkan bahkan selain mengurangi masalah pembuangan sampah, kompos yang dihasilkan dapat dimanfaatkan sendiri, tidak perlu membeli.

a. Pilahkan sampah organik (sampah dapur dan halaman) dan sampah non organik, komposisi terbesar dari sampah rumah tangga sekitar $70 \%$ sebenarnya adalah sampah organik dan ini bisa ditahan di rumah, dan diolah menjadi kompos. Jenis sampah organik yang bisa diolah menjadi kompos itu adalah sampah sayur baru sisa sayur basi, tapi ini harus dicuci dulu, peras, lalu buang airnya sisa nasi sisa ikan, ayam, kulit telur sampah buah (anggur, kulit jeruk, apel, dII). Dalam keadaan terpotong-potong, tidak termasuk kulit buah yang keras seperti kulit salak.

b. Sampah organik yang tidak bisa diolah: protein seperti daging, ikan, udang, juga lemak, santan, susu (karena mengundang lalat sehingga tumbuh belatung) biji-biji yang utuh atau keras seperti biji salak, asam, lengkeng, alpukat dan sejenisnya. Buah utuh yang tidak dimakan karena busuk dan berair seperti pepaya, melon, jeruk, anggur.

Kompos berguna untuk memperbaiki struktur tanah, zat makanan yang diperlukan tumbuhan akan tersedia (Harlis et al, 2019). Mikroba yang ada dalam kompos akan membantu penyerapan zat makanan yang dibutuhkan tanaman. Tanah akan menjadi lebih gembur. Tanaman yang dipupuk dengan kompos akan tumbuh lebih baik. Pengomposan merupakan salah satu alternatif pengolahan limbah padat organik (organik solid waste) yang dapat diterapkan di Indonesia, mengingat bahan baku terutama sampah perkotaan (municipal waste) tersedia berlimpah, dan teknologi tepat guna untuk proses pengomposan pun telah cukup dikuasai.

\section{METODE}


Metode pelaksanaan kegiatan berupa pembinaan, keterampilan dan pemberian materi serta demonstrasi kepada peserta. Kegiatan ini dilakukan selama 3 (bulan) bulan mulai dari perencanaan, pelaksanaan pelatihan hingga pembuatan dan presentasi laporan kegiatan.Berikut uraian tahapan kegiatan yang dilakukan pada Pelatihan Pengelolaan Sampah Rumah Tangga dengan Metode Komposting di Desa Kerinjing, Kecamatan Tanjung Raja, Ogan Ilir.

Kegiatan pengabdian ini dilaksanakan pada hari Rabu tanggal 1 November 2017 di Desa Kerinjing dengan jumlah peserta sebanyak 26 orang di Balai Desa Kerinjing Kecamatan Tanjung Raja, Ogan Ilir.Narasumber adalah dosen Fakultas Ekonomi Unsri Jurusan Ekonomi Pembangunan dengan dibantu oleh mahasiswa sebagai panitia pendukung.

Khalayak sasaran kegiatan pengabdian ini adalah masyarakat Desa Kerinjing, Kecamatan Tanjung Raja, Kabupaten Ogan Ilir.Masyarakat yang diundang dalam kegiatan pelatihan ini sesuai dengan tujuan kegiatan PPM adalah masyarakat desa khususnya ibu-ibu anggota PKK perwakilan masing-masing dusun sebanyak 26 orang. Evaluasi dilakukan dengan cara membagikan kuesioner yang berhubungan dengan materi kegiatan "Pelatihan Pengelolaan Sampah Rumah Tangga dengan Metode Komposting di Desa Kerinjing".

\section{HASIL DAN PEMBAHASAN}

Pelatihan pengolahan sampah rumah tangga dengan menggunakan metode komposting dilaksanakan secara informal secara sistematis dan terstuktur. Peserta yang mengikuti pelatihan ini sebanyak 26 ibu-ibu rumah tangga dan remaja putri. Tujuan dilakukannya kegiatan pengabdian masyarakat adalah untuk meningkatkan pengetahuan dan memberdayakan masyarakat tentang pengeloaan sampah. Kegiatan dilaksanakan dengan membagikan handout yang berkaitan dengan materi (tata cara pemanfaatan sampah rumah tangga dengan menggunakan metode komposting) dan penyampaian materi oleh Ketua Pelaksana dan dibantu juga Tim Anggota Pelaksana.

Pada saat demontrasi, para pelaku masyarakat diharapkan dapat mempraktekkan juga cara pembuatan pupuk kompos dengan sampah rumah tangga yang setiap hari nya semakin meningkat seiring dengan pertambahan penduduk. Manfaat yang diharapkan dari kegiatan pengabdian kepada masyarakat adalah pertama, sebagai wahana untuk meningkatkan pengetahuan dan wawasan khalayak sasaran dalam pengelolaan sampah rumah tangga dengan metode komposting. Kedua, untuk memberikan alternatif pengeloaan sampah rumah tangga di desa Kerinjing, yang secara tidak langsung juga memberdayakan masyarakat untuk mengolah sampah organik menjadi pupuk kompos yang selanjutnya dapat untuk pupuk tanaman ataupun dijual

\subsection{Kerangka Solusi}

Dari kegiatan pengabdian ini, dapat disimpulkan bahwa masih banyak masyarakat desa yang belum mengetahui membedakan sampah anorganik dan sampah organik, ataupun sampah yang bisa cepat diurai maupun tidak bisa terurai. Selain itu, masyarakat juga masih tidak tahu manfaat yang dihasilkan dari pengelolaan sampah dengan benar yang bisa menambah nilai ekonomis. Pengetahuan masyarakat tentang sampah masih sangat minim, mereka tidak bisa melihat peluang yang dihasilkan dari menumpuk nya tumpukan sampah rumah tangga yang semakin hari semakin banyak.

Peran masyarakat dalam pengelolaan sampah diperlukan tidak hanya sebatas membuang sampah di tempat yang seharusnya, namun diharapkan termasuk juga pengolahan sampah yang memberikan manfaat kembali bagi masyarakat itu sendiri (Dewi, Y.S, 2012). Dalam hal ini sebagai salah satu bentuk tanggung jawab dosen dalam melaksanakan Tridarma perguruan Tinggi, maka perlu diadakan pengabdian pada masyarakat berupa pelatihan pengelolaan sampah rumah tanga dengan metode sederhana, yaitu komposting. Menurut Cundari, L, et al (2019), Tingkat pengetahuan warga terhadap pengelolaan sampah secara umum masih relatif kecil, secara ratarata hanya $48 \%$. Hal ini dipengaruhi oleh pendidikan warga yang tingkat dasar (SD) mencapai $48 \%$. Untuk pengalaman warga dalam mengelola sampah sudah cukup baik, yaitu sebanyak $53 \%$

Oleh karena itu, salah satu solusi awal yang dapat digunakan masyarakat dalam mengatasi masalah tersebut adalah dengan pengetahuan manfaat yang dihasilkan cara pengelolaan sampah 
dengan menggunkaan metode komposting. Dengan adanya pelatihan bagi ibu-ibu PKK perwakilan dusun-dusun di Desa Kerinjing tentang pengelolaan sampah rumah tangga dengan metode komposting yang dikemas dalam paket pengabdian masyarakat oleh Tim Dosen dari Fakultas Ekonomi Universitas Sriwijaya, maka dapat ditularkan kepada ibu-ibu di lingkungan sekitarnya sehingga akan sangat membantu dalam menjaga kebersihan lingkungan, mengurangi volume sampah yang dibuang ke lingkungan, menyuburkan tanaman di pekarangan/ lahan pertanian, dan peningkatan pendapatan.

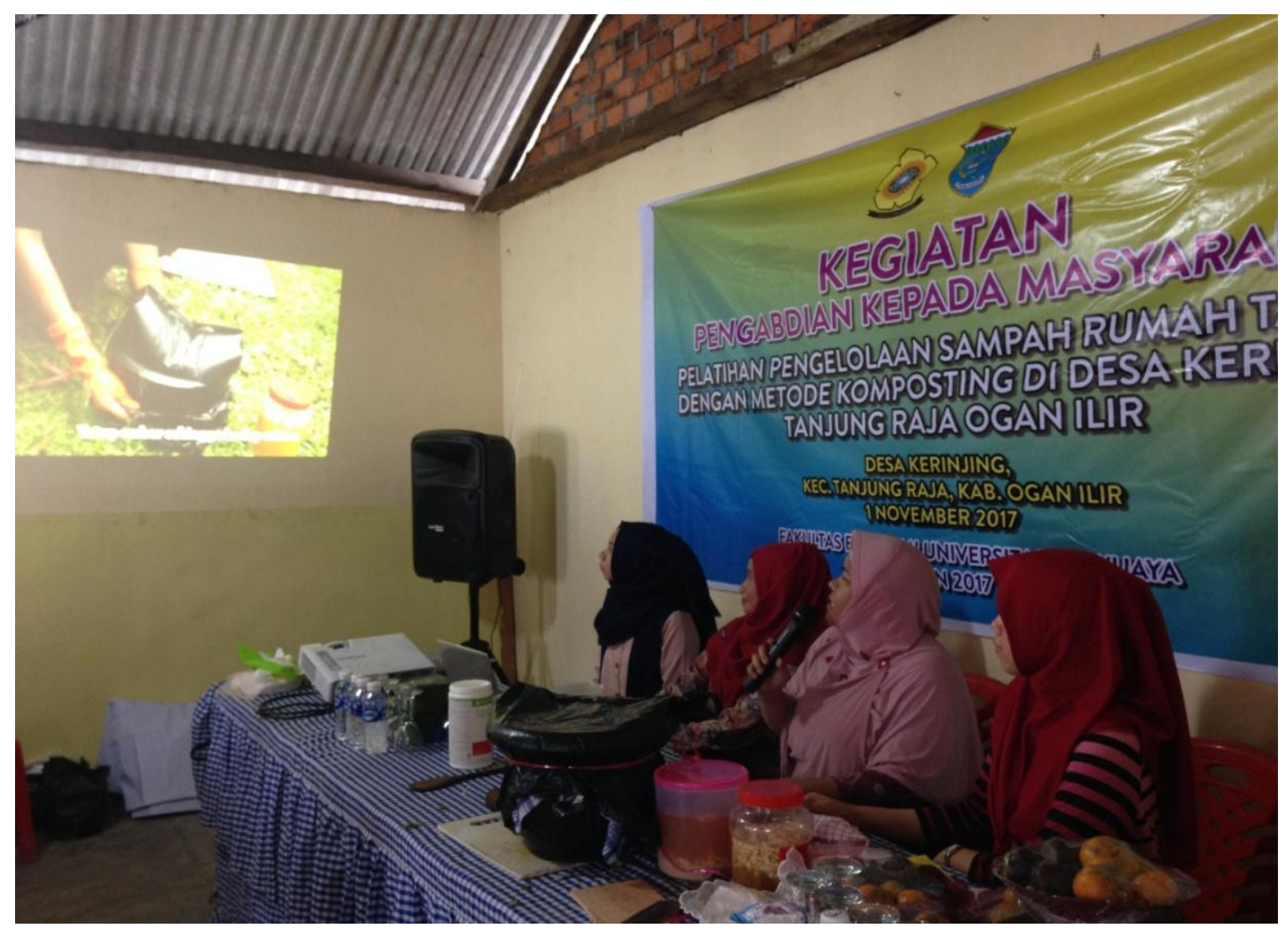

Gambar 1. Penyampaian Materi oleh Narasumber

Setelah penyampaian materi selesai, maka langsung melakukan demontrasi/ praktek cara pembuatan pupuk kompos dari sampah rumah tangga dengan metode komposting. Demonstrasi dilakukan dengan harapan peserta pelatihan dapat melaksanakan simulasi secara sempurna tentang pengelolaan sampah rumah tangga dengan metode komposting. Peserta diperkenankan untuk bertanya dan mendemontrasikan secara langsung langkah-langkah pembuatan pupuk kompos tersebut. 


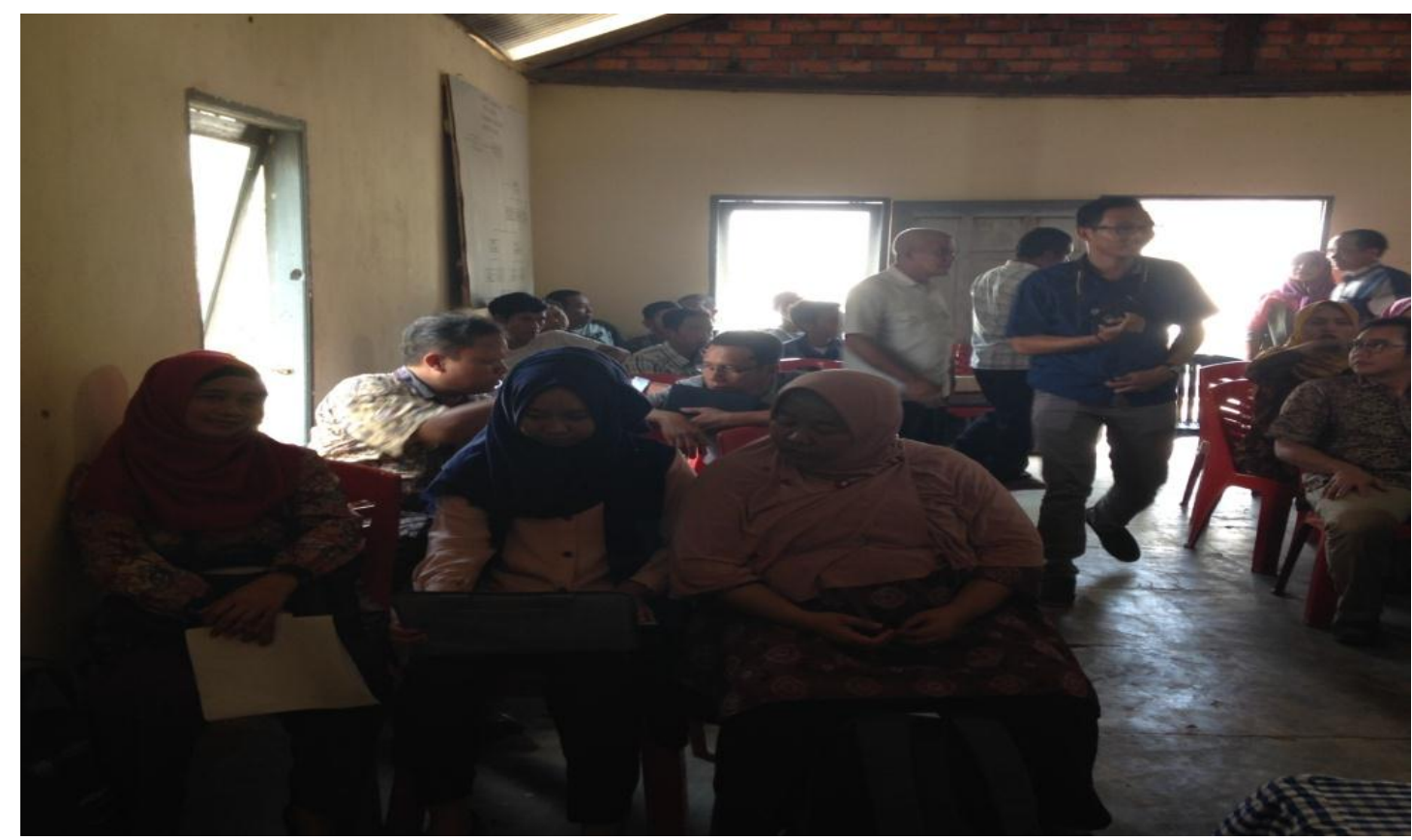

Gambar 2. Kegiatan Pengabdian tentang Pengelolaan Sampah Rumah Tangga

\section{SIMPULAN}

Masyarakat di Desa Kerinjing sering mengabaikan dan tidak tahu pemanfaatan sisa sampah rumah tangga yang memiliki nilai ekonomis. Dari sisi kepentingan lingkungan, pengomposan dapat mengurangi volume sampah yang dibuang ke Tempat Pembuangan Akhir (TPA), karena sebagian di antaranya khususnya sampah padat organik dimanfaatkan ulang dan diolah menjadi kompos.Dari sisi ekonomi, pengomposan sampah padat organik mengandung arti, bahwa barang yang semula tidak memiliki nilai ekonomis dan bahkan memerlukan biaya yang cukup mahal untuk menanganinya serta akhir-akhir ini sering menimbulkan masalah sosial, ternyata dapat diubah menjadi produk yang bermanfaat dan bernilai ekonomis cukup menjanjikan.

Diharapkan dengan adanya pelatihan bagi ibu-ibu PKK perwakilan dusun-dusun di desa Kerinjing tentang pengelolaan sampah rumah tanga dengan metode komposting yang dikemas dalam paket pengabdian masyarakat oleh Tim Dosen dari Fakultas Ekonomi Universitas Sriwijaya, maka dapat ditularkan kepada ibu-ibu di lingkungan sekitarnya sehingga akan sangat membantu dalam menjaga kebersihan lingkungan, mengurangi volume sampah yang dibuang ke lingkungan, menyuburkan tanaman di pekarangan/ lahan pertanian, dan peningkatan pendapatan.

\section{UCAPAN TERIMA KASIH}

Terima kasih kepada Fakultas Ekonomi Universitas Sriwijaya yang telah mendanai kegiatan pengabdian ini melalui dana PNBP Fakultas.

\section{REFERENSI}

Angeliana, D. (2016). Meningkatkan Pemahaman Masyarakat Melalui Sosialisasi Persampahan dan Rumah Sehat di Permukiman Tempat Pembuangan Akhir (TPA) Desa Neglasari, Tangerang. Jurnal Abdimas, 2(2), 12-17.

Cundari, L., Arita, S., Komariah, L. N., Agustina, T. E., \& Bahrin, D. (2019). Pelatihan dan pendampingan pengolahan sampah organik menjadi pupuk kompos di desa burai. Jurnal Teknik Kimia, 25(1), 5-12. https://doi.org/10.36706/jtk.v25i1.14.

Dewi, Y.S. (2012). Pengolahan Sampah Skala Rumah Tangga Menggunakan Metode Komposting. Jurnal IImiah Fakultas Teknik LIMIT'S, 8(2). 
Harlis H., Yelianti, U., Budiarti S.R., \& Hakim, N. (2019). Pelatihan Pembuatan Kompos Organik Metode Keranjang Takakura sebagai Solusi Penanganan Sampah di Lingkungan Kost Mahasiswa. DEDIKASI: Jurnal Pengabdian Masyarakat, 1(1), 1-8.

Oktiawan, W \& Amalia, S. (2012). Pengaruh Kondisi Sistem Drainase, Persampahan Dan Air Limbah Terhadap Kualitas Lingkungan (Studi kasus Kelurahan Kuningan Kecamatan Semarang Utara), Jurnal Presipitasi: Media Komunikasi dan Pengembangan Teknik Lingkungan, 9(1), 41-50. https://doi.org/10.14710/presipitasi.v9i1.41-50.

Notoatmodjo, S. (2015). Metodologi Penelitian Kesehatan. Jakarta: PT Rineka Cipta.

Puspitawati, N., \& Sulistyarini, T. (2013). Sanitasi Lingkungan yang Tidak Baik Mempengaruhi Status Gizi pada Balita. Jurnal STIKES, 6(1), 74-83.

Suparmi., Khotimah, N., Sumunar, D.R.S., Sudarsono, A., Setyawati, S. (2013). Pelatihan Pengelolaan Sampah Rumah Tangga dengan Metode Komposting di Desa Banyurejo Kecamatan Tempel Kabupaten Sleman. Laporan Kegiatan PPM. Yogyakarta: Universitas Negeri Yogyakarta. 